$$
\text { 4. } \alpha_{2} \text {-マクログロブリンの臨床* }
$$

安藤宏・小島 䒨 雄**

$\alpha_{2}$ マクログロブリン（以下 $\alpha_{2} \mathbf{M}$ と略す）は沈降恒 数 19.3S, 分子量約 82 万の糖蛋白で通常血清蛋白の 2 乃至 $5 \%$ を占めるとされ，ネフローゼ症候群，肝硬変， 楉尿病，感染症，等で增加するととが知られている。近 年になってての蛋白の生化学的知見がふえ，trypsin， plasmin, elastase 等の protease 作用汇影響を及ぼし, 又 growth hormone や insulin と結合する作用がある等, 生理的機能の面も次第に明らかになって来た。

我々はこれら $\alpha_{2} \mathrm{M}$ に関する問題点のうち， $\alpha_{2} \mathrm{M} の$ 分離法, 測定法, ついで $\alpha_{2} \mathrm{M}$ 正常值の年令的変化並ひ に性差について, 更に各種疾患時の血清 $\alpha_{2} \mathrm{M}$ の生理的 機能のうち, trypsin と plasmin に対する作用について 述へるととにする。

\section{I. $\alpha_{2} \mathrm{M}$ の分離}

高純度の $\alpha_{2} \mathrm{M}$ 標品は免疫学的測定の際の標準蛋白及 ひ，抗血清作成の際の抗原としてのみならず，乙の蛋白 の生物学的諸機能を検討する上で必要であるが， $\alpha_{2} \mathrm{M}$ の分離精製には実際上かなりの困難が伴う。分離法は Schultze ${ }^{1)}$ 等の最初の記載以来数多くの方法が報告され ているが，てれらの方法の多くは，第1 段階でェタノ一 几分画の Fr III-O から出発するものや硫安塩析，リバ ノール沈殿，殿粉ブロック電気泳動等のいずれかを行な い，第 2 段階で分離用超遠心又はセファデックス G-200 ゲル沪過を用い，第 3 段階には DEAE セルローズヌは DEAE 女フォデックスによるクロマトグラフィー等を 用いて精製している。最終的に $\beta$-lipoprotein や haptoglobin の混入が生じやすいので，デキストラン硫酸を 用いたり，塩析に際しあらかじめ hemoglobin を加える 等の工夫がなさている。

我々の教室では小スケールの分画には通常第 1 段階に 殿粉ブロック電気泳動を用いているが，血清 100〜200 $\mathrm{m} l$ から出発する際は第 1 段階に硫安塩析を用いている。

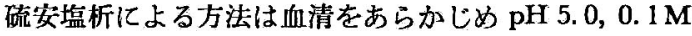
の燐酸緩衝液で 4 倍に稀釈し硫安塩析を行なう。硫安濃
度 $2.07 \mathrm{M}$ と $2.40 \mathrm{M}$ との間で沈殿する蛋白を透析濃樎 したのち $0.5 \mathrm{M}$ 食塩加 $\mathrm{pH} 7.0$ 燐酸緩衝液でセファデ ックス G-200 ゲル沪過を行なう。溶出した第 1 峰の前 半を $0.015 \mathrm{M}, \mathrm{pH} 5.0$ 酶酸縟衝液を starting buffer にし DEAE セルローズカラムでイオン强度を変えた gradient elution を行なうと $0.040 \mathrm{M}$ で溶出する第 1 峰は haptoglobin の混入がない高純度の $\alpha_{2} \mathrm{M}$ である。この様にし て得た標品を我々は抗血清作成の際の抗原と, 免疫学 的測定の際倹量線を作るのに用いている。抗血清は家 鬼にて作成しているが $\alpha_{2} \mathrm{M}$ 標品を微量（1 回量 Img, 2 回感作）免疫するととにより，単一の沈降線を示す特 異抗血清が得られる（図 1-1）。図 1-2 は $\alpha_{2} \mathrm{M}$ 標品の電 顥像である。

しかしながらての様な分離法にかなりの時間(約 5 日)

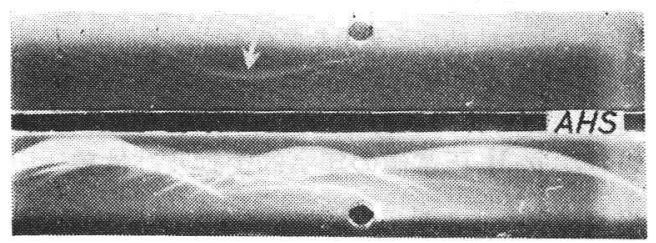

図 1-1 上は $\alpha_{2} \mathrm{M}$ 分画

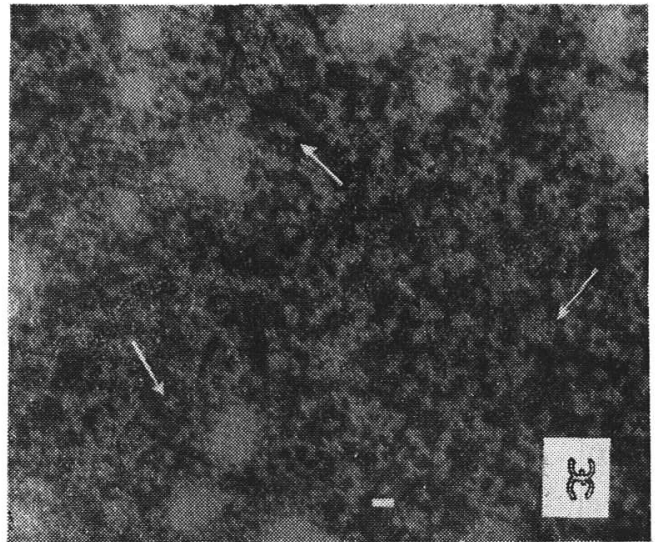

図 1-2 $\alpha_{2} \mathrm{M}$ の電顕像及び模式図, scale は $200 \AA$

* Clinical studies on $\alpha_{2}$-macroglobulin

**Hiroshi Ando and Mineo Kojima 岐皁大学医学部第 1 内科 
を要する為変性が生じやすいことや，又 $\alpha_{2} \mathrm{M}$ 自身 protease と結合したままの状態でとり出されることが多 いこと年等, 生物学的活性の検討に使用出来る標品を取 り出すことは今日な执むずかしく，てれまでに報告され ている生物学的諸作用についても各研究者の間でかなり かけ離れた結果が示されて拉り, 分画法の一層の改良が 望まれところである。

\section{II. $\boldsymbol{\alpha}_{2} \mathbf{M}$ の測定法}

血清 $\alpha_{2} \mathrm{M}$ の測定には従来，特異抗血清を用いた種々 の免疫学的定量法が用いられているが，我々はてれまで 比較的再現性が良く, 又多数の検体を一度に処理出来る 利点をむった single radial immunodiffusion 法を行なっ て来た。この方法は著しい高值を示す検体では抗原過剩 となる為沈降輪が不鮮明となり, 又 $\alpha_{2} \mathrm{M}$ 濃度との間に 直線性が保たれない為, 最適比の領域まで検体を稀釈し て測定を行なう必要がある。したがって寒天板の厚さ と，抗体及び測定する試料を適当に稀釈するてとにより 最低 $20 \mathrm{mg} / \mathrm{d} l$ までの試料が測定可能であり，それ以 下の試料, 例えば尿や他の体液等の $\alpha_{2} \mathrm{M}$ を測定する場 合は, immunoelectrodiffusion 法を用いている。乙の方 法を用いると最低 $1 \mathrm{mg} / \mathrm{d} l$ の濃度までが測定可能であ る。乙れら免疫学的測定法の他飞， $\alpha_{2} \mathrm{M}$ の trypsinprotein esterase 活性を利用した測定法があるが，あとで 述べるととにする。

\section{III. $\alpha_{2} M$ 正常値の年令的変動及び性差}

各種疾患時の $\alpha_{2} \mathrm{M}$ を測定するにあたり，まず健康者

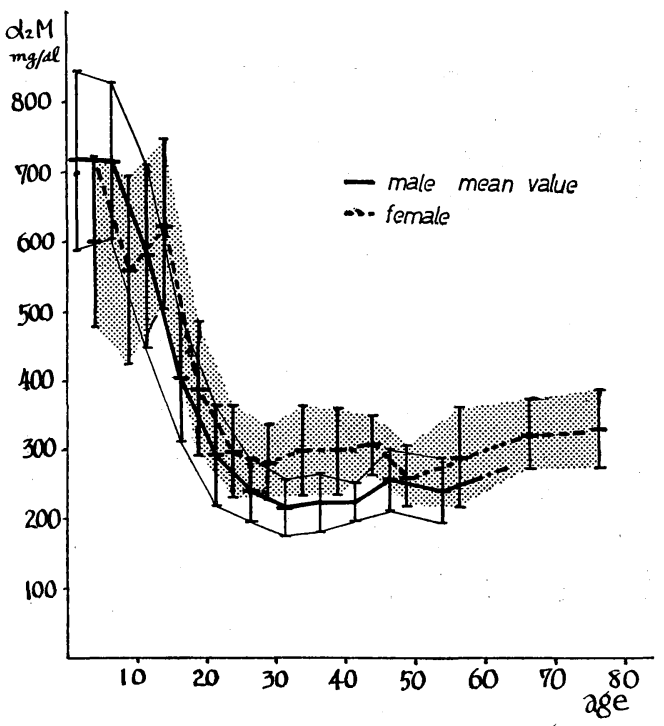

図 2 Serum $\alpha_{2} \mathrm{M}$ level in normal subjects
血清 $\alpha_{2} \mathrm{M}$ 值を測定しててれを年令別並に性別の各群に 分けて各群の差を検討した。対象としては健康診断等の 機会を利用して 3 才から 80 才までの男女約 800 名から 採血し, そのうち肝機能や尿検査, 血球検查等に異常を 認めたものを除く男子 318 例，女子 329 例について血清 $\alpha_{2} \mathrm{M}$ 值を測定し，乙れらを5才毎の群に分けてそれぞ れの平均值と標準偏差を求めた（図 2 , 表 1 )。男女共

表 1 各年令群男女の正常値

\begin{tabular}{|c|c|c|c|}
\hline 年 令 構 成 & 例 数 & 平均 值 & 標準偏差 \\
\hline 1〜5才 & $\begin{array}{l}\text { 숭 } 10 \\
\text { 우 } 9\end{array}$ & $\begin{array}{l}718.4 \\
599.7\end{array}$ & $\begin{array}{l}129.5 \\
122.2\end{array}$ \\
\hline $6 \sim 10$ & $\begin{array}{l}\text { 송 } 52 \\
\text { 우 } 32\end{array}$ & $\begin{array}{l}717.5 \\
559.5\end{array}$ & $\begin{array}{l}122.0 \\
136.5\end{array}$ \\
\hline $11 \sim 15$ & $\begin{array}{l}\text { 숭 } 18 \\
\text { 우 } 21\end{array}$ & $\begin{array}{l}580.5 \\
623.0\end{array}$ & $\begin{array}{l}131.5 \\
126.4\end{array}$ \\
\hline $16 \sim 20$ & $\begin{array}{l}\text { 송 } 59 \\
\text { 우 } 74\end{array}$ & $\begin{array}{l}403.4 \\
385.5\end{array}$ & $\begin{array}{l}93.0 \\
98.5\end{array}$ \\
\hline $21 \sim 25$ & $\begin{array}{l}\text { 송 } 43 \\
\text { 우 } 19\end{array}$ & $\begin{array}{l}292.0 \\
296.5\end{array}$ & $\begin{array}{l}77.5 \\
69.5\end{array}$ \\
\hline $26 \sim 30$ & $\begin{array}{l}\text { 송 } 24 \\
\text { 후 } 12\end{array}$ & $\begin{array}{l}240.0 \\
279.0\end{array}$ & $\begin{array}{l}47.6 \\
51.4\end{array}$ \\
\hline $31 \sim 35$ & $\begin{array}{l}\text { 숭 } 21 \\
\text { 우 } 28\end{array}$ & $\begin{array}{l}215.6 \\
298.4\end{array}$ & $\begin{array}{l}41.0 \\
67.6\end{array}$ \\
\hline $36 \sim 40$ & $\begin{array}{l}\text { 今ิ } 33 \\
\text { 우 } 28\end{array}$ & $\begin{array}{l}220.8 \\
297.0\end{array}$ & $\begin{array}{l}39.8 \\
61.6\end{array}$ \\
\hline $41 \sim 45$ & $\begin{array}{l}\text { 소 } 24 \\
\text { 우 } 26\end{array}$ & $\begin{array}{l}223.2 \\
306.8\end{array}$ & $\begin{array}{l}28.6 \\
42.8\end{array}$ \\
\hline $46 \sim 50$ & $\begin{array}{l}\text { ㅎㅇㅇ } 10 \\
\text { 후 } 18\end{array}$ & $\begin{array}{l}256.0 \\
263.6\end{array}$ & $\begin{array}{l}46.0 \\
42.8\end{array}$ \\
\hline $51 \sim 60$ & $\begin{array}{l}\text { 옹 } 16 \\
\text { 우 } 31\end{array}$ & $\begin{array}{l}239.2 \\
286.5\end{array}$ & $\begin{array}{l}46.6 \\
73.8\end{array}$ \\
\hline $61 \sim 70$ & $\begin{array}{lr}\text { 홍 } 3 \\
\text { 우 } 15\end{array}$ & $\begin{array}{l}477.0 \\
320.0\end{array}$ & $\overline{51.6}$ \\
\hline $71 \sim 80$ & $\begin{array}{lr}\text { 옹 } & 4 \\
\text { 우 } 13\end{array}$ & $\begin{array}{l}374.5 \\
327.0\end{array}$ & $\overline{43.4}$ \\
\hline $81 \sim$ & $\begin{array}{ll}\text { 合 } & 1 \\
\text { ㅇ } & 3\end{array}$ & $\begin{array}{c}(427.0) \\
275.3\end{array}$ & - \\
\hline
\end{tabular}

小児期では健康成人の值の 2 乃至 2.5 倍に及ぶ高值を示 し，20才頃までには成人の值まで下がる。女子では 10 才から 15 才までの思春期に相当する時期に最高值を示 し，以後 40 才から 50 才頃まで男子より高值を保ってい る。乙のうち 21 才から 60 才までの男女（男 166 例，女 165 例） について各々の平均値と標準偏差を求めると, 男 $245.2 \pm 59.4 \mathrm{mg} / \mathrm{d} l$, 女 $290.0 \pm 63.2 \mathrm{mg} / \mathrm{d} l$ で有意水準 0.01 で女子の高值が認められる。乙の值は Ganrot $^{3)}$ の 正常值や Haverback $\left.{ }^{4}\right)$ のあのよりやや高いが，James や Housley $\left.{ }^{6}\right)$ の值より低い。乙れは測定法による差の他 に，対象とした健康者の年令層の差にもよるむのと思わ れる。又男女差については女子が男子より約 $20 \%$ 高く $\mathrm{Ganrot}^{3)}$ の報告と一致している。小児期に高值を示す 
理由については growth hormone ${ }^{7)}$ 乃至 growth factor ${ }^{8}$ との関係が論ぜられているが，女子で高い理由について は議論が分かれており, 今日尚推察の域を出ない。しか し女子で思春期に相当して最高值を示すことや妊娠の後 半に高值を示すこと采等体内ホルモン環境の差が男女差 の形成に関与している様に思われる。いずれにしてもこ の様に $\alpha_{2} \mathrm{M}$ は年令的変動や性差が著しいので, 疾患時 の変動をみる際には，乙の様な正常值の特徵を十分考慮 する必要がある。

\section{IV. 各種疾患時の $\boldsymbol{\alpha}_{2} M$ 值について}

腎疾患で高値を示すむのはネフローゼ症候群に多い
が，なかでむ著しい高值を示すむのは 20 才以下のむの が大部分を占めている。腎生検所見ではネフローゼ症候 群のうちmembranous type, proliferative type を示すむ ので高いむのが多い。次に腎の蛋白クリアランスについ て検討を行なった（表 2 )。IgG クリアランスと Tf ク リアランスの此, 即ち $\mathrm{C}_{\mathrm{Ig}} / \mathrm{C}_{\mathrm{Tf}}$ の值が 0.20 以上のむ のは尿中に $\alpha_{2} \mathrm{M}$ が出現して找り，これらの群では臨床 上ステロイドが無効か又は殆んど効果が認められなかっ た。

ネフローゼ症候群での $\alpha_{2} \mathrm{M}$ の増加について Kluthe 等 ${ }^{10)}$ は turnover の研究加ら, 系球体撰択性による血中 貯留と循環血漿量の減少に原因があるとしている。我々

表 2 尿 $\alpha_{2} \mathrm{M}$ と分子量別蛋白クリアランス

\begin{tabular}{|c|c|c|c|c|c|c|c|c|c|c|}
\hline & 症 例 & 年 & 性 & 生 検 所 見 & $\begin{array}{l}\text { Steroid } \\
\text { 効 果 }\end{array}$ & $\begin{array}{c}\mathrm{T} . \mathrm{P} \\
\mathrm{mg} / \mathrm{d} l\end{array}$ & $\mathrm{Ig} G / T f$ & $\alpha_{2} \mathrm{M} / \mathrm{Tf}$ & $\mathrm{C}_{\mathrm{Ig}} \mathrm{G} / \mathrm{C}_{\mathrm{Tf}}$ & $\mathrm{C} \alpha_{2} \mathrm{M} / \mathrm{C}_{\mathrm{Tf}}$ \\
\hline 1 & H. K & 33 & 우 & Membranous & 無 & 600 & 1.95 & 0.004 & 0.32 & 0.046 \\
\hline 2 & G. T & 73 & 今 & Minimal change & 不完 (A) & 200 & 0.20 & - & 0.05 & - \\
\hline 3 & R. $\mathrm{N}$ & 17 & 우 & Proliferative & 不完 (B) & 1,100 & 0.17 & - & 0.06 & - \\
\hline 4 & S.U & 13 & 今 & Lobular & 未 不 変 & 350 & 0.84 & 0.027 & 0.21 & 0.014 \\
\hline 5 & H. T & 35 & 古 & Proliferative & 未 & 340 & 0.13 & - & 0.05 & - \\
\hline 6 & M. T & 18 & 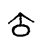 & Sclerosing & 不完 (A) & 400 & 0.28 & - & 0.10 & 一 \\
\hline 7 & S. T & 27 & 今 & Acute nephritis & 未 & 90 & 0.45 & - & 0.19 & - \\
\hline 8 & R.M & 19 & 우. & "I & 未 & 650 & 0.39 & - & 0.12 & - \\
\hline 9 & I. I & 30 & 우 & $S \mathrm{~L} \mathrm{E}$ & 無 （死） & 580 & 2.00 & 0.039 & 0.21 & 0.023 \\
\hline
\end{tabular}

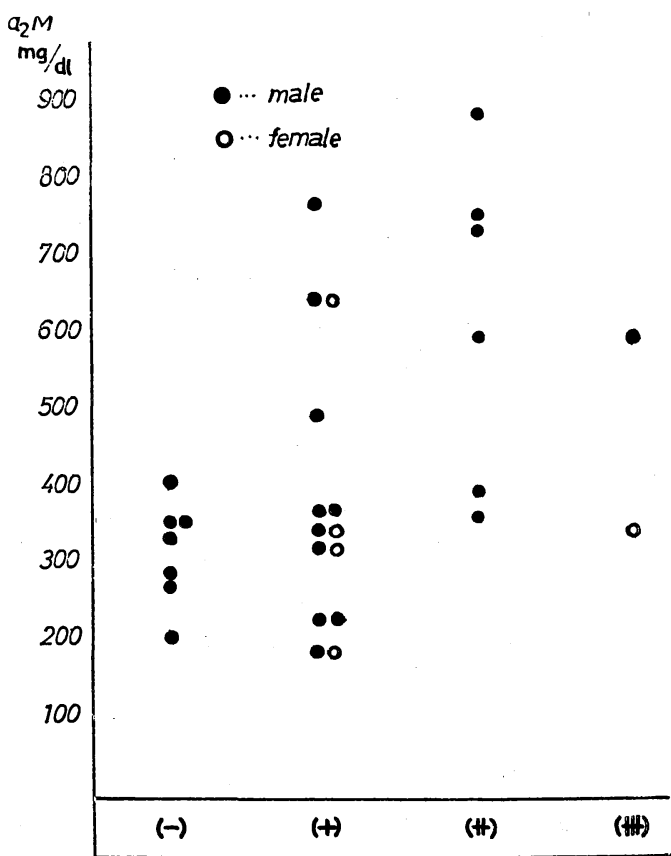

グ氏鞘細胞渗潤

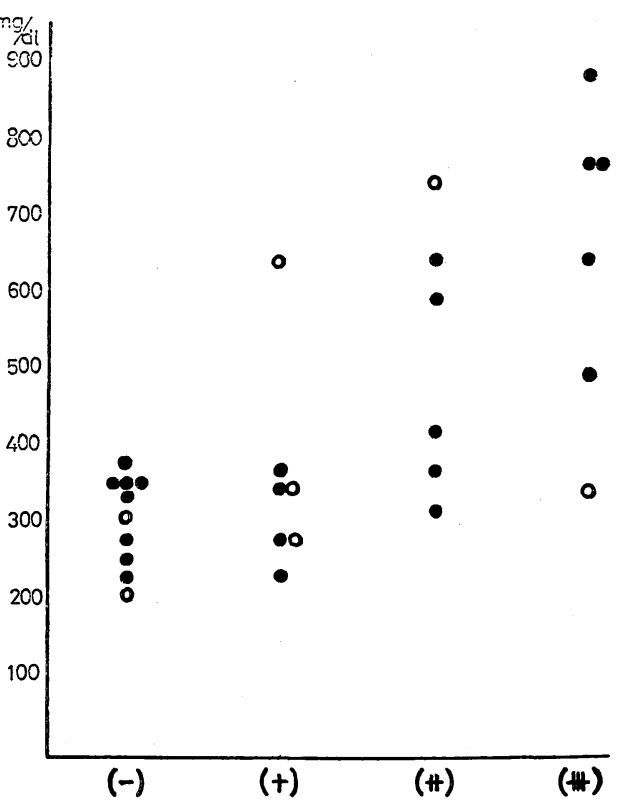

結合織増殖

図 $3 \alpha_{2} \mathbf{M}$ と肝組織像 
の症例で著しい高値を呈するむのはすべて 20 才以下の 症例であって, 若年者では $\alpha_{2} \mathrm{M}$ 産生の盛んなととと, 血中貯留, 循環血漿量の減少等の原因が加わって著明な 高值を示すものと考えられる。したがって腎疾患の臨床 上重要なととは， $\alpha_{2} \mathrm{M}$ の血中濃度よりむむしろ尿中へ の出現であって，尿中への $\alpha_{2} \mathrm{M}$ 出現の有無を知ること はステロイド効果を予測する上で有用である様に思われ る。

次に肝疾患についてみてみると，肝生検を施行した 28 例のうち，急性肝炎では $\alpha_{2} \mathrm{M}$ はすべて正常範囲にある が, 慢性肝炎, 肝硬変と進むにしたがって $\alpha_{2} \mathrm{M}$ は上昇 する傾向にある。肝組織像では $\alpha_{2} \mathrm{M}$ 高值を示すむのは， すべてにグ氏鞘内細胞浸潤が認められるが，浸潤の程度 とは必しむ平行関係になく，むしろ細胞浸潤が中等度の 群で $\alpha_{2} \mathrm{M}$ は高い。乙れに対して結合織増生の程度とは 良い相関を示している（図 3 )。

糖尿病では $\alpha_{2} \mathrm{M}$ がしばしば高值を示すものがあり， 糖尿病患者を Boas の式にしたがい, やせ型, 正常型, 肥 満型の 3 群に分けて $\alpha_{2} \mathrm{M}$ をみてみると，やせ型に高い あのが集中しているのに対し，正常型では中等度上昇を みるものがあり，肥満型ではほとんど正常簳囲内にある （図 4)。乙れを合併症の有無加らみてみると，腎障害や 肝障害を合併するすのは一般に高く, 網膜症を合併する
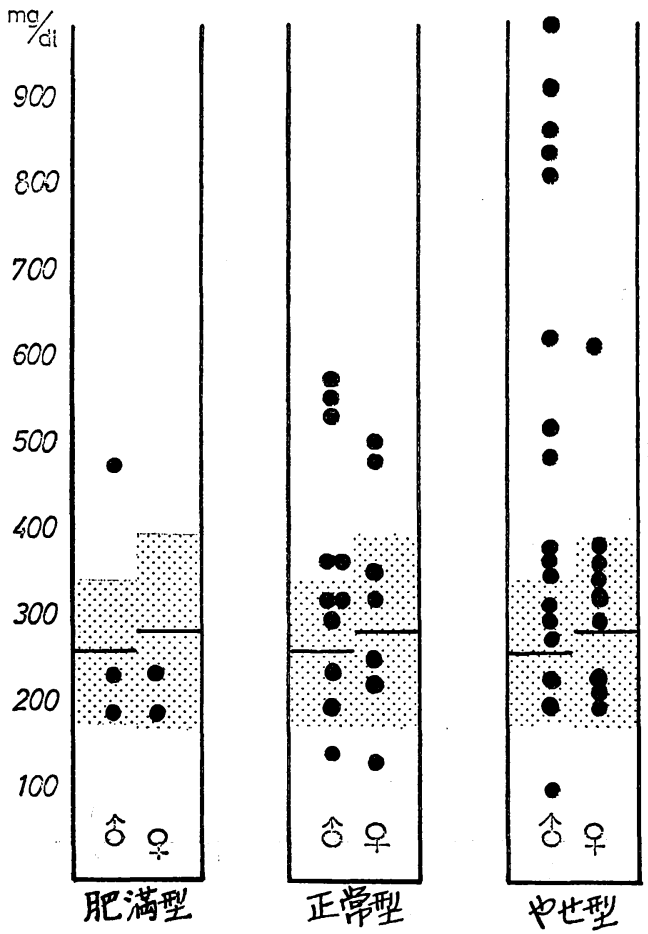

図 4 糖尿病患者の体型之 $\alpha_{2} \mathrm{M}$
あのの一部が軽度上昇している。合併症が臨床上認めら れない群で, 罹病期間 5 年以上の群では中等度上昇を示 している。次に insulin との関係が論ぜられている ${ }^{11 \sim 12)}$ ので，血清 IRI 值との関係をみてみたが特に相関を示 さず，又血糖負荷曲線から耐糖能との関係をみたが，耐 糖能の悪いむのであ必ずしも $\alpha_{2} \mathrm{M}$ は高くなかった。

感染症では比較的慢性の経過をとる胆石症や胸膜炎等 で軽度上昇がみられ，悪性腫瘍であ軽度上昇を示すが， 血液疾患では年令的要因を除くとほほ正常值にあり，口 イマチ様関節炎では従来報告されている様な増加は認め られなかった。又甲状腺機能六進症で軽度上昇がみられ た。

この様に $\alpha_{2} \mathrm{M}$ は疾患の急性期に增加するいわゆる急 性相反応因子ではなく, 肝疾患や糖尿病及び慢性感染症 等にみられる様に，長期に渉る経過中に徐々に增加する 蛋白の様である。 $\alpha_{2} \mathrm{M}$ は trypsin, plasmin, thrombin, elastase 等の antiprotease として作用することがわかっ ているが，乙の様な protease は炎症の治痖過程で重要 な働きをあつものと思われ13)，乙うした protease の増加 に伴って血清中の normal inhibitor である $\alpha_{2} \mathrm{M}$ の増加 が生ずるのではなかろうか。

\section{V. $a_{2} M$ の抗 plasmin 及び抗 trypsin 作 用について}

一般に $\alpha_{2} \mathrm{M}$ 高㯰を示ずすのの全血清抗 plasmin を clot lysis time で測定すると，10 時 間以上延長するすの が多く認められる。しかし血清中には $\alpha_{2} \mathrm{M}$ の他に， $\alpha_{1}-$ antitrypsin, $\alpha_{1}$-antichymotrypsin, inter- $\alpha$-trypsin inhibitor ${ }^{14)}$ 等があって，いずれむ抗 plasmin 作用をあつむ のとされている。我々は $\alpha_{2} \mathrm{M}$ を分離する第 1 段階と同 一の塩析条件で血清の硫安塩析を行ない，てれをセファ デックス G-200 でゲル沪過を行ない，それぞれの分画 の clot lysis time と $\alpha_{2} \mathrm{M}$ 及び $\alpha_{1}$-antitrypsin の濃度を 測定した。第 1 峰に一致して lysis の延長がみられ, $\alpha_{2} \mathrm{M}$ の分布とむよく一致している（図 5 )。しかし $\alpha_{2} \mathrm{M}$ の抗 plasmin 作用は他の血清中抗 plasmin に比しては るかに弱いあのの様である。分離精製した $\alpha_{2} \mathrm{M}$ につい て抗 plasmin 作用をみてみたが, 各 lot で変性の割合が 異なる為か一定の結果が得られなかった。

次に trypsin に対する作用についてみてみた。trypsin 活性の測定は基質 benzoyl-DL-arginine-p-nitroanilid$\mathrm{HCl}$ が加水分解を受ける際の吸光度の增加を $410 \mathrm{~m} \mu$ で 測定した。血清 $30 \mu l$ に trypsin を漸增して加えると， trypsin 活性は僅かに上昇したあと，血清中の抗 trypsin 為一定の活性に留まるが，trypsin が $100 \mu \mathrm{g}$ を越えると 


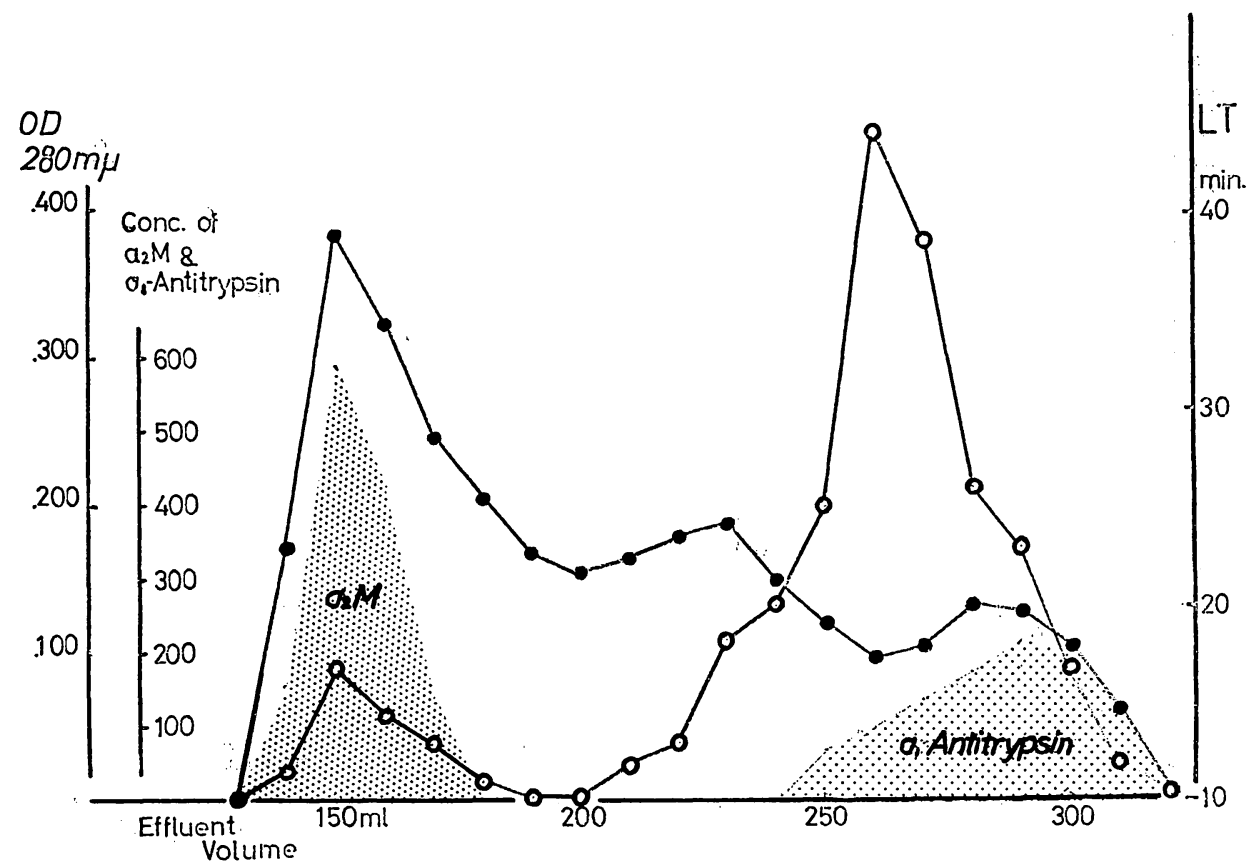

図 5 血清硫安塩析分画 $(2 M \sim 2.3 M)$ の Sephadex G-200 ゲル沪過による anti-pl の分布

急に上昇する。次に trypsin $5 \mathrm{mg}$ をあらかじめ血清 $3 \mathrm{~m} l$ に加えてセファデックス G-200 ゲル沪過を行なったと ころ trypsin 活性は高分子の FrI のみにあるが，乙の血 清の抗 trypsin 作用は未だかなり残っている。このとと は trypsin と高分子蛋白が速やかに結合し, 又他の抗 trypsinよりとの結合の affinity が強い為, trypsin 活性 が protect されるものと思われる。trypsin 活性を保持し て血清蛋白と結合した複合体は trypsin-protein binding complex ${ }^{15)}$ と呼ばれている。乙の場合保持された活性は 又 trypsin-protein esterase 活性（以下 TPE 活性）と呼 ばれている。血清のセファデックス G-200 分画では(図 6) TPE 活性は FrI にのみ存在し, 抗 trypsin 活性に

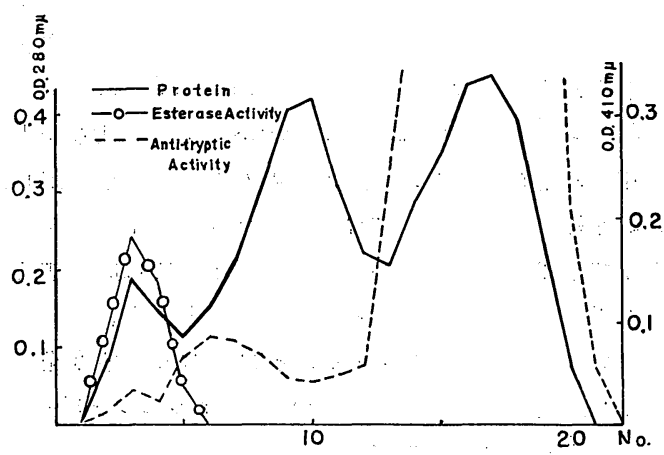

図 6 Sephadex G-200により gel 沪過分画し た血清の TPE 活性と抗 trypsin 活性
は3つの peak があり, FrI の小さな抗 trypsin 活性は TPE 活性と平行してその約 18\% 亿相当する。乙の Fr I 飞 IgM, IgA, $\beta$-lipoprotein 等の抗血清を加えると, 抗 $\alpha_{2} \mathrm{M}$ を加えたすののみ活性の低下があり TPE 活性は $\alpha_{2} \mathrm{M}$ によるものと思われる。乙の TPE 活性によっても $\alpha_{2} \mathrm{M}$ を測定することが可能で, 正常者と各種疾患者血 清について TPE 活性と immunodiffusion 法で測定した $\alpha_{2} \mathrm{M}$ 值との関係は $\mathrm{r}=0.86$ の相関が認められる (図 7)。 TPE 活性の生理的意義ははっきりしないが， $\alpha_{2} \mathrm{M}$ が他 の inhibitor の作用を protect して運ぶいわゆる carrier protein の働きをするすのの様に思われる。

次に我々は精製した $\alpha_{2} \mathrm{M}$ を $1 \%$ 燐タングステン酸カ リで, negative staining を行なって電子顕微鏡で観察し たところ $\mathrm{H}$ 型， $\mathrm{H}+\mathrm{I}$ 型等の粒子が散見せられた。この 粒子が $\alpha_{2} \mathrm{M}$ の分子そのあのかどうかは不明であるが, $\alpha_{2} \mathrm{M}$ が trypsin と結合して protect する作用をむち, 他 の protease の inhibitor として作用し, growth hormone と結合する等の性質を考え合せるとき示唆に富んだ構造 である様に思われる。

終りに臨み終始御指導をたまわった恩師乾成美教授に 深く感謝致します。 


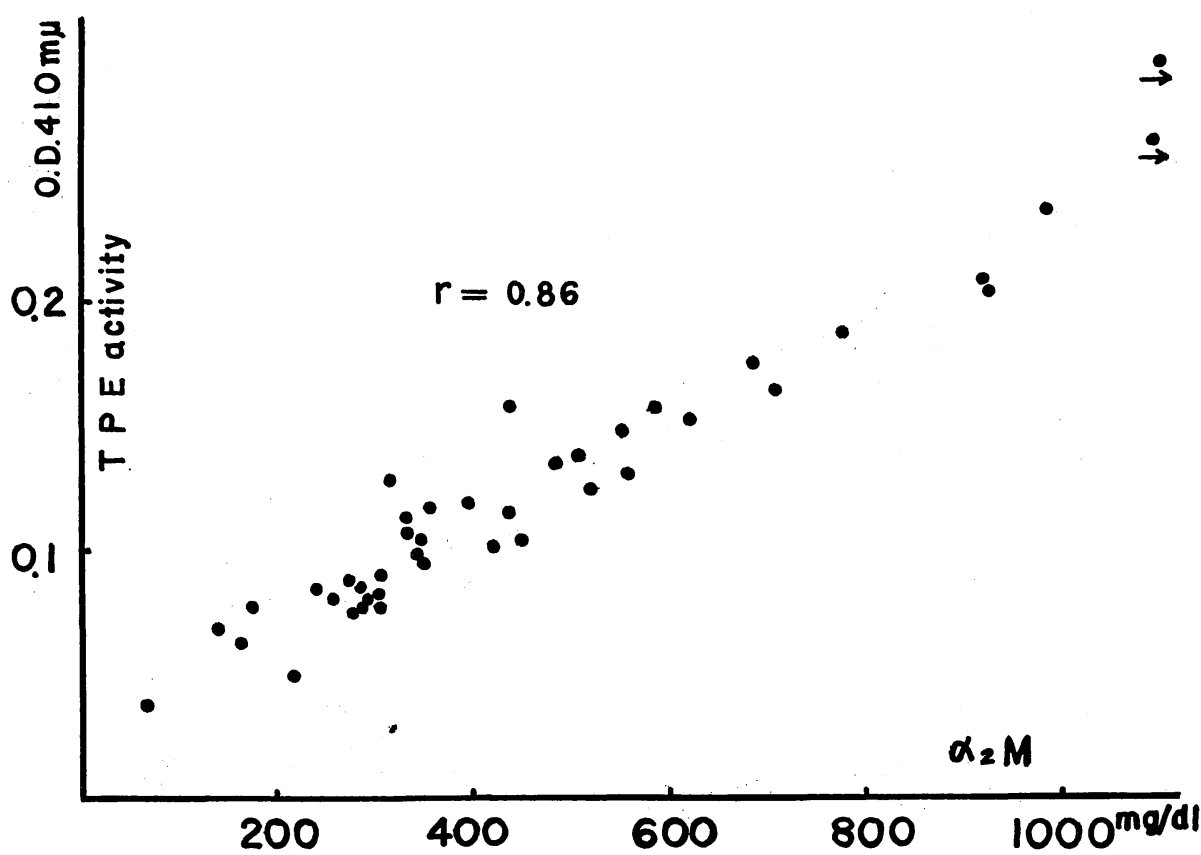

図 7 患者及び正常者の血清中 TPE 活性と $\alpha_{2} \mathrm{M}$

\section{文献}

1) H. E. Schultze, I. Göllner, K. Heide, M. Schönenberger, and G. Schwick: Z. Naturforsch. 106, 463 (1955)

2) M. Steinbuch, L. Pejaudier, M. Quentin, V. Martin: Biochim. Biophys. Acta 154, 228 (1968)

3) D. O. Ganrot and B. Scherstén: Clin. Chim. Acta 15, 113 (1967)

4) N. F. Adham, P. Wilding, J. Mehl and B. J. Haverback: J. Lab. J. Clin. Med 7, 271 (1968)

5) K. James, G. Johnson and H. H. Fudenberg: Chin. Chim A.cta 14, 207 (1966)

6) J. Houslly: J. Chin. Path. 21, 27 (1968)

7) D. R. Hadden, and T. E. Prout: Nature 202, 1342 (1964)

8) G. M. Healy and R. C. Parker: J. Cell Biol. 30, 539 (1966)

9) D. O. Ganrot and B. Bjerre: Acta Obst. et Gynec. Scand. 46, 126 (1967)

10) R. Kluthe, U. Hagemann and N. Kleine: Vox Sang. 12, 308 (1967)

11) G. R. Zahnd, and J. J. Scheidegger: Helv. Med. Acta 30, 506 (1963)

12) M. F. Keehan, M. J. Smith, S. M. Howard, J. W. Mehl and P. M. Beigelman: Clin. Chim. Acta 16, 215 (1967)

13) K. Udaka, and H. Hayashi: Biochem. Biophyo. Acta 97, 251 (1965)

14) H. G. Schwick, N. Heimburger und H. Hanpt:
Zschr. inn. Med. 21, 193 (1966)

15) B. J. Haverback, B. Dyce, H. F. Bundy S. K. Wirtschafter and H. A. Edmondson: J. Clin. Invest 41, 972 (1962)

〔追加〕日大・医・臨床病理 河 合 忠

日常検査として，小児期の血清をセ・ア電気泳動法お よび免疫電気泳動法で分析している際に $\alpha_{2}$ 分画とくに $\alpha_{2}$-マクログロブリンが著しく高值を示す事に注目した。 種々の年令層について $\alpha_{2}$-マクログロブリンを検索する と, 生後次第に増加し $1 \sim 2 才 に$ 最高值を示し正常成人 值の $2 \sim 3$ 倍に達する。その後漸次減少し思春期になっ て正常成人值を示すようになる。この増加傾向は小児期 の成長曲線によく類似しており， $\alpha_{2}$-マクログロブリン と成長の間に密接な関連性を有することと推定し現在検 索中である。Ganrot (Scand. J. Glin. Lab. Investi. 21, 177, 1968) は trypsin-protein esterase (TPE) 活性を用い て種々の動物血清中の $\alpha_{1}-$ マクログロブリンを測定した 成績を報告している。すなわち，ラッテおよびウシでは 成長するにつれて逆に増加を示し，イヌでは成長するに つれてごくわずか増加するに過ぎないという。したがっ て，ヒト $\alpha_{2}$-マクログロブリンとは異なった態度を示し て扣り， $\alpha_{2}$-マクログロブリンが成長ホルモン作用をむ っているとは考えられない。 
〔質問〕東大・医・小児科 吉 野 加津哉

1) $\alpha_{2} \mathrm{M}$ の正常值がかなり高いが，抗原として用いだ $\alpha_{2} \mathrm{M}$ が $\beta$ リリホ蛋白, $\gamma \mathrm{M}$ などを微量に含んでいるた め，それに対する抗体ができているためではないか。

2）インスリンと結合する蛋白に対して否定的な見解で あると考えてよいか。 また糖尿病のやせ型に $\alpha_{2} \mathrm{M}$ が 高いというが, 他疾患（感染症）との合併のためでは ないか。

3) 胎帯血の $\alpha_{2} \mathrm{M}$ の測定值は如何。
〔答〕岐阜大・医・ 1 内安藤宏

1) $\alpha_{2} \mathrm{M}$ の值が特に小児で高いのは, 抗原の.純度の問 題よりあ, むしろ, 試料が少なかったため, 適度な稀 釈で測定できなかったあのがあるめかと考えるので今 後検討したい。(河合氏の迫加参照)

2）インスリンとの関係は血清 IRI 值との相関からの 結論である。また糖尿病の型別についての検討は, 本 文中の通りであるが, 今後尚例数を重ねて検討する。

3）臍帯血についての分析は適当な試料のないため行な っていない。 